\title{
ESTRATEGIAS DE REPRESENTACIÓN DE LA FRASE NOMINAL RELATIVIZADA EN ESPAÑOL
}

\author{
Mario Portilla Chaves
}

\begin{abstract}
RESUMEN
En el presente trabajo, se presenta una caracterización de las estrategias pragmáticas de representación de la frase nominal relativizada en las oraciones subordinadas relativas del español, desde una perspectiva tipológico-funcional.
\end{abstract}

ABSTRACT

This article describes the pragmatic strategies used to express the relativized noun phrase within the relative clause in Spanish, according to a functional-typological approach.

\section{Introducción}

Una definición generalmente aceptada de las oraciones relativas es que son cláusulas subordinadas que funcionan como un modificador nominal. Por ello, la cláusulas relativas presentan ciertos elementos que se relacionan tanto semántica como formalmente con otros de la cláusula principal. El presente trabajo pretende caracterizar la forma en que una frase nominal presente en la cláusula principal (el antecedente) se representa en la cláusula subordinada relativa en español, desde una perspectiva tipológico-funcional ${ }^{1}$.

\section{Elementos de la oración relativa}

Desde un punto de vista tipológico, en español, se pueden reconocer tres elementos que están implicados en la formación de una oración relativa:

1. El antecedente de la oración relativa. El antecedente es la frase nominal que está modificada por la oración relativa.

Tú no eres la persona [a quien yo espero]. 
En la oración anterior, el antecedente corresponde a la frase nominal la persona.

2. La frase nominal relativizada. Esta es el elemento dentro de la cláusula relativa que es correferencial con la frase nominal antecedente.

Tú no eres la persona [a quien yo espero].

En la oración anterior, la frase nominal relativizada que es correferencial con la frase nominal antecedente (la persona) está representada por el pronombre relativo quien.

3. El relativizador. Es el elemento que relaciona la cláusula relativa con la cláusula principal y la subordina a ella.

Tú no eres la persona [a quien yo espero].

En la oración anterior el relativizador es el mismo pronombre relativo quien.

En este punto, hay que mencionar que el autor considera que no todos los relativizadores deberán ser considerados pronombres relativos ${ }^{2}$.

Un pronombre relativo propiamente dicho desempeña una función anafórica que expresa ciertas características semánticas o ciertas propiedades gramaticales de la frase nominal relativizada. En el caso de la oración anterior, por ejemplo, el pronombre relativo quien expresa el número singular de la frase nominal relativizada (la persona).

Es común que esta característica de referencialidad anafórica propia de los pronombres aparezca expresada formalmente por medio de la concordancia. Esta puede ser solamente de número, como se ha visto en la oración anterior (cf. Ustedes no son las personas [a quienes yo espero]) o de género y número como en las siguientes oraciones.

El asunto [del que me hablas] me aburre.

Siempre nos contaba anécdotas de su juventud, [la cual había sido interesante].

Desde este punto de vista, el relativizador que no debe ser considerado un pronombre relativo, sino más bien un nexo subordinador sin contenido semántico, sin valor referencial o anafórico. Como sucede en muchas otras lenguas, este relativizador es formalmente idéntico al completizador que introduce las cláusulas subordinadas completivas.

El tantas veces señalado carácter invariable del relativizador que, es decir, la total ausencia de concordancia con la frase nominal antecedente, demuestra que su función en el proceso de relativización no es la de representar la frase nominal antecedente.

Este hecho se nota claramente en la siguiente oración, cuya ambigüedad sobre quién es el agente del verbo matar no puede ser despejada si el relativizador es el subordinador que.

El tigre [que mató el elefante] también murió.

Cf. El tigre [al que mató el elefante] ...

El tigre [que mató al elefante]... 
Otro de los argumentos que se puede esgrimir para afirmar que el relativizador que no es un pronombre relativo es el hecho de que este elemento no puede estar precedido por el marcador del argumento de objeto directo, la preposición $a$.

*El tigre [a que mató el elefante]...

La agramaticalidad de la oración anterior se debe a que el marcador de objeto directo (la preposición $a$ ) es una parte integrante del argumento gramatical en cuestión. El relativizador que no representa este argumento ni forma parte de él, como lo hacen otros relativizadores que sí son pronombres relativos, como se nota en las siguientes oraciones.

El hombre al que vi...

El hombre al cual vi...

El hombre a quien vi...

*El hombre a que vi...

Lo mismo sucede con los marcadores del argumento de objeto indirecto, las preposiciones a o para, como en los siguientes casos.

El jefe para el que trabajo...

El jefe para el cual trabajo...

El jefe para quien trabajo ...

*El jefe para que trabajo...

Tomando en cuenta las consideraciones anteriores, el autor propone la siguiente tipología de las estrategias de representación de la frase nominal relativizada en las oraciones subordinadas relativas del español.

\section{Formas de expresar la FN relativizada}

\subsection{Estrategia del espacio vacío}

Esta estrategia consiste en representar la frase nominal relativizada por medio de un espacio vacío. El contexto lingüístico permite al hablante suponer el lugar que la frase nominal relativizada ocuparía dentro de la oración relativa. Es decir, el contexto de la oración permite reconstruir la función gramatical que desempeña la frase nominal relativizada dentro de la cláusula relativa, aunque esta no aparezca realmente en ella, como en los siguientes ejemplos.

Las personas [que $\emptyset$ consumen mucha grasa] deben hacer ejercicio físico.

Esta no es ya la ciudad [que conocí $\varnothing]$.

Las funciones gramaticales de sujeto y de objeto directo, respectivamente, que presenta la frase nominal relativizada de cada una de las oraciones anteriores, pueden fácilmente suponerse debido a la concordancia que aparece en la marcación verbal. 
En español, el uso de la estrategia del espacio vacío está acompañada del empleo del relativizador que como el elemento subordinador que introduce la cláusula relativa.

Es interesante señalar que la posible ambigüedad que se puede presentar por la falta de un elemento anafórico y de una concordancia verbal aclaradora, como la que ocurre en la oración mencionada anteriormente El tigre que mató el elefante también murió, suele desaparecer por el contexto mismo del discurso. Probablemente, en casos como estos, los hablantes recurrirían a otras estrategias de representación de la frase nominal relativizada para evitar la ambigüedad, como en las oraciones antes citadas:

El tigre al que mató el elefante ...

El tigre que mató al elefante...

\subsection{Uso de pronombres relativos}

Como se ha dicho, los pronombres relativos tienen una función anafórica que permite recuperar ciertas características semánticas y gramaticales de la frase nominal relativizada. Como en otras lenguas, en español, muchos de los pronombres relativos permiten expresar la función gramatical que desempeña la frase nominal relativizada dentro de la cláusula relativa.

Es la conciencia [quien nos impone límites]. Función de sujeto

La persona [a quien me enviaste] prometió ayudarme. Función de O.D.

El gerente, [con quien acabo de hablar], prometió devolverme el dinero.

Función de O. de preposición

\subsection{Retención de pronombre}

Esta estrategia consiste en utilizar, dentro de la cláusula relativa, un pronombre personal o posesivo que se refiera al antecedente, que concuerde con él.

Este tipo de estrategia se usa menos frecuentemente en español y es más bien propio del habla coloquial. En este caso, al igual que con la estrategia del espacio vacío, se utiliza el relativizador que como subordinador que introduce la cláusula relativa.

Me encontré con un español [que lo había conocido en Madrid].

Función de O.D.

En la oración anterior, el pronombre personal lo representa la frase nominal relativizada un español, con la cual concuerda en género, número y persona. La forma de objeto directo del pronombre personal refleja la función que cumple la frase nominal relativizada dentro de la cláusula subordinada.

Otros ejemplos del uso de esta estrategia en la que se relativizan otras funciones son los siguientes: 
Usted fue el único [que le compramos un regalo tan caro]. Función de O.I. Me llamó el compañero [que sus papás trabajan en la universidad]. Función de poseedor Este fue el muchacho [que [parece que] lo asaltaron el otro día]. Función de O.D. ¿Dónde está el paquete [que lo puse aquí]? Función de O.D.

\section{Conclusiones}

La tipología de las estrategias de representación de la frase nominal relativizada en las oraciones subordinadas relativas del español incluye el uso de un espacio vacío, el uso de pronombres relativos y el uso de pronombres personales y posesivos.

\section{Notas}

1. Este trabajo está enmarcado dentro de la perspectiva teórica de la tipología funcionalista descrita en Payne 1997.

2. La discusión sobre la relación entre los pronombres relativos y la conjunciones completivas fue inaugurada por Andrés Bello a mediados del siglo XIX. Para un recuento histórico de la polémica, véanse Rivero 1991 y, más recientemente, Brucart 1999.

\section{Bibliografía}

Bello, Andrés. 1847. Gramática de la lengua castellana destinada al uso de los americanos. Madrid: Arco/Libros.

Brucart, José María. 1999. La estructura del sintagma nominal: las oraciones de relativo. En Bosque \& Demonte 1999: 395-522.

Bosque, Ignacio \& Violeta Demonte. 1999. Gramática descriptiva de la lengua española. Madrid: Espasa.

Payne, Thomas. 1997. Describing morphosyntax. Cambridge: Cambridge University Press.

Rivero, María Luisa. 1991. Las construcciones de relativo. Madrid: Taurus. 